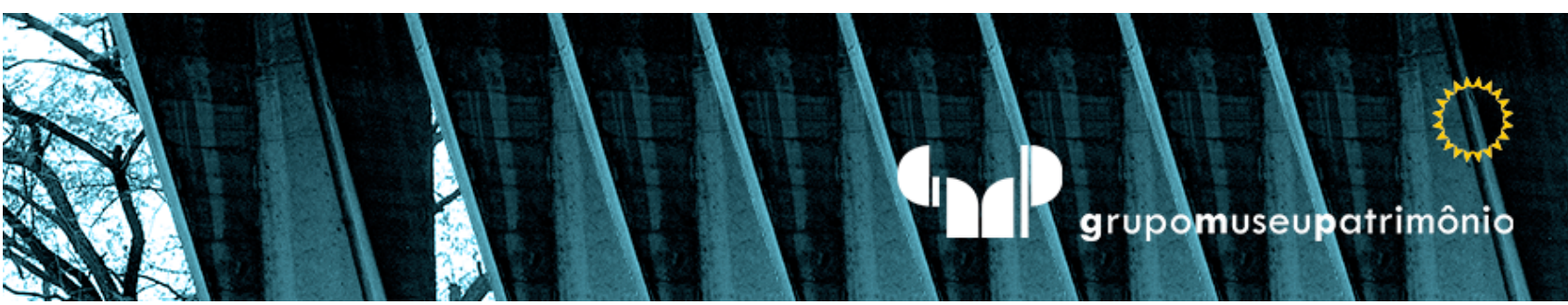

\title{
Imagens em movimento: sintomas e frestas em experiência da pandemia ${ }^{1}$
}

\section{Imágenes en movimiento: síntomas y grietas en las experiencia pandémica}

\section{Moving images: symptoms and cracks in pandemic experience}

\footnotetext{
${ }^{1}$ Artigo desenvolvido a partir de pesquisa de pós-doutorado intitulada Percursos: narrativas cotidianas da cidade, realizada na Faculdade de Arquitetura e Urbanismo da Universidade de São Paulo (FAU USP) sob a supervisão da Profa. Dra. Titular Sênior Maria Cecília França Lourenço.
} 


\title{
Resumo
}

O objetivo do artigo é refletir sobre a representação da cidade de São Paulo durante o isolamento para o combate à pandemia do vírus Sars-Cov-2, causador da Covid-19, e constituir memória desse período invulgar. Para tanto, apresenta imagens realizadas pela autora durante $o$ ano de 2020 em percursos pela cidade nos quais 0 solo, os corpos sentados ou deitados no meio-fio e nas calçadas surgem como importantes sintomas das fissuras do atual arranjo social vigente. Organização que exclui completamente milhares de pessoas da cidadania, tratando-as como restos, refugo a ser descartado, desconsiderado e apagado, corpos que, no entanto, resistem e sobrevivem. A partir de experiência da autora, o trabalho visa restituir ao coletivo as imagens e postular a urgente necessidade de se imaginar novas perspectivas, frestas abertas para novas composições possíveis.

Palavras-chave: São Paulo. Sintoma. Fresta. Pandemia. Experiência. Imagem.

\section{Resumen}

El objetivo del artículo es reflexionar sobre la representación de la ciudad de São Paulo durante el aislamiento para combatir la pandemia del virus Sars-Cov-2, causante del Covid-19, y constituir un recuerdo de este inusual periodo. Para ello, presenta imágenes tomadas por el autor durante el año 2020 en recorridos por la ciudad en los que el suelo, los cuerpos sentados o tumbados en las aceras aparecen como síntomas importantes de las fisuras del ordenamiento social actual vigente. Organización que excluye por completo de la ciudadanía a miles de personas, tratándolas como restos a descartar, desatendidas y borradas, cuerpos que, sin embargo, resisten y sobreviven. A partir de experiencia del autor, el trabajo pretende devolver las imágenes al colectivo y postular la urgente necesidad de imaginar nuevas perspectivas, abrir grietas para nuevas composiciones posibles.

Palabras-clave: São Paulo. Síntoma. Grieta. Pandemia. Experiencia. Imagen.

\begin{abstract}
The objective of the article is to reflect on the representation of the city of São Paulo during the isolation to combat the pandemic of the Sars-Cov-2 virus, which caused Covid-19, and to constitute a memory of this unusual period. To this end, it presents images taken by the author during the year 2020 on routes through the city in which the soil, the bodies sitting or lying on the curb and on the sidewalks appear as important symptoms of the cracks in the current social arrangement in force. An organization that completely excludes thousands of people from citizenship, treating them as remains to be discarded, disregarded and erased, bodies that however resist and survive. Based on the author's experience, the work aims to restore the images to the collective and postulate the urgent need to imagine new perspectives, open cracks for new possible compositions.
\end{abstract}

Keywords: São Paulo. Symptom. Crack. Pandemic. Experience. Image. 
[...] "não sei se vamos sair dessa experiência da mesma maneira que entramos.

É como um anzol, nos puxando para a consciência.

Um tranco para olharmos para o que realmente importa".

Ailton Krenak (2020, p. 12).

"Qual o valor de todo o nosso patrimônio cultural, se a experiência não mais o vincula a nós?"

Walter Benjamin (1987, p. 115).

\section{INTRODUÇÃO}

isolamento social imposto para combater a pandemia da Covid-19, iniciado oficialmente em São Paulo no dia 24 de março de 2020, transformou radicalmente o uso habitual da cidade. Quem antes tinha maior oportunidade de movimentação e interação com o território, ainda que baseadas na mercantilização do espaço urbano ${ }^{2}$, notadamente os mais ricos e escolarizados, pôde ficar em casa

\footnotetext{
${ }^{2}$ Para Milton Santos (2007) cidadão não é aquele que pode consumir, atividade apontada pelo geógrafo como uma das mais alienantes que existem, mas aquele que constrói a cidadania, compreendida como conquista coletiva efetivada por individualidades conscientes e não individualistas. Santos põe em xeque a cidade do expert e vê a da comunidade regulada pelo Estado com base na participação ativa dos cidadãos, para evitar que o espaço e os lugares sejam exclusivamente determinados pelas forças do mercado. A cidade mercantilizada, portanto, é uma cidade sem cidadania e sem cidadãos, mesmo para aqueles que têm dinheiro para consumir, pois foi transformada em objeto de consumo imediato e não de construção comunitária ativa.
} 
trabalhando remotamente, consumir via internet e aplicativos de entrega, encontrar amigos e familiares virtualmente ou mesmo aproveitar sua casa de campo e de praia para aliviar a tensão das incertezas do período.

Esvaziados de quase metade de seus cidadãos e usuários, os espaços públicos da capital paulista foram ocupados por aqueles que não tinham outra possibilidade para sobreviver senão sair às ruas para trabalhar, vender nos sinais, pedir ajuda ou morar. Em julho, no entanto, a flexibilização da quarentena (oficial ou decidida individualmente, inclusive sem seguir as regras de proteção), levou de volta ao comércio físico - shoppings, lojas de rua, ambulantes, bares e restaurantes - muitas pessoas que estavam em casa e que doravante passam por entre os que não chegaram a sair das ruas ou nelas pararam nos últimos cinco meses ${ }^{3}$, numa estranha sobreposição de vivências e contrastes.

Um período incomum como esse seria capaz de proporcionar às pessoas experiências verdadeiramente profundas e transformadoras? Seriam elas realmente esse anzol para uma consciência coletiva na qual outros seres humanos e o planeta estariam incluídos enquanto vidas importantes? Ou teriam perdido o sentido e o vínculo,

\footnotetext{
${ }^{3}$ De acordo com dados da Revista Piauí, a onda da covid-19 se espalhou do centro para a periferia, ao contrário do movimento habitual de muitas doenças. O Sars-CoV-2, vírus causador da enfermidade, chegou ao Brasil trazido por pessoas de maior poder aquisitivo, atingindo bairros de classe média e alta do centro expandido de São Paulo que ocuparam leitos de hospitais particulares. Numa segunda fase de disseminação, o vírus se espalhou pelo centro expandido em momento de transmissão sustentada, ainda demandando a maioria dos leitos em hospitais privados. Na sua terceira fase de contágio, o SarsCoV-2 se espalhou pelas periferias da cidade e as internações passaram a estressar o Sistema Único de Saúde, que chegou perto do colapso. Segundo o texto, "o avanço da covid-19 pela periferia de São Paulo coincide com um momento em que a população começa a afrouxar medidas de isolamento social" (ROSSI, 2020). Já em agosto, o jornal Folha de S. Paulo ainda aponta que enquanto $22 \%$ dos moradores dos distritos mais pobres da cidade já foram infectados pelo novo coronavírus, em bairros de renda média essa porcentagem cai para $18,4 \%$ e nos bairros mais ricos para $9,4 \%$. O número de mortos também se concentra nos bairros periféricos (BOTTALLO, 2020, s.p.). Os efeitos da pandemia sobre os mais pobres têm sido mapeados por pesquisas coordenadas por universidades públicas e institutos de pesquisa, mas mesmo sem ter números exatos, quem circula pela cidade constata que o número de moradores de rua em São Paulo (estimado em mais de 24 mil pessoas no início de 2020 pelo censo realizado pela Prefeitura de São Paulo) está visivelmente maior durante a pandemia, como atestam os serviços de atendimento voluntário da cidade. As refeições fornecidas às pessoas pelos serviços aumentaram 10 vezes no Movimento Estadual da População em Situação de Rua (de 200 pratos subiu para 2000) e passou de 50 a 2.500 na tenda do Serviço Franciscano de Solidariedade (SEFRAS). 0 aumento se deveu à falta de renda e recursos para pagar seus aluguéis e seu sustento (LARA, 2020, s.p.) e os novos sem-teto são desempregados, imigrantes e refugiado. Os resultados futuros, aliados à crise econômica que toma o globo, apontam para um agravamento da crise social que já vem se aprofundando nos últimos 5 anos.
} 
dando lugar a um crescente individualismo, a uma humanidade fragmentada em pequenas tribos, castas e estamentos fundados sobre noções competitivas e bélicas nas quais há sempre o perverso par vencedores/derrotados?

Diante dessa situação atípica e da necessidade de se experimentar e representar ${ }^{4} 0$ momento para restituí-lo à coletividade, como importante reflexão, de que maneira se poderia cartografar ${ }^{5}$ insurgências e desvios neste urbano modificado? Como vivenciar e representar o estado alterado do espaço mediante um olhar movente que se apresenta como perspectiva de apreensão parcial e mediada da materialidade e das práticas da cidade? O ponto de vista que percorre, que passa sem ficar, e as pessoas que ali se fixam reduziriam o patrimônio edificado a mero cenário dos gestos que caracterizam as resistências, os levantes ${ }^{6}$, termos estes no dizer de Georges Didi-Huberman (2019, p. 56)?

Dar respostas únicas a essas perguntas seria reduzi-las a uma exatidão impensável, planificá-las, esvaziar sua complexidade e a de vários estratos de vivências e representação. No artigo, em que se apresentam experiências fotográficas

\footnotetext{
${ }^{4}$ Para Roger Chartier (1990) as representações são instrumentos de significação do mundo social. As diversas representações compõem discursos articulados em formações socioculturais. São sempre matizadas por interesses, imaginários e ideologias, motivo pelo qual não poderiam ser retratos fiéis da realidade, mas processos de compreensão e construção do mundo por parte dos diferentes grupos. $\mathrm{Na}$ mesma linha, Georges Didi-Huberman trabalha com o conceito de representação como um processo interpretativo de conhecimento daquilo que se apresenta diante de cada um (2020, p.9).

${ }^{5}$ Mapas são, em sua origem, representações cartográficas em duas dimensões que se destinam a descrever e interpretar o espaço (HARLEY, 1991, p. 5). Podem ser discursos de poder para facilitar o controle e a vigilância, esvaziando socialmente os espaços representados, ou, em uma acepção mais abrangente, funcionar como desenhos em movimento dos afetos, "mergulho nas intensidades do passado para ressignificá-las no presente" (ROLNIK, 2011, p.231). São, pois, instrumentos para concepção de outras formas espaciais nas quais incluem-se as artes, os saberes tradicionais, sonhos e desejos de modo a estimular o pensamento crítico, a imaginação e a ação cidadã. Entre as práticas cartográficas que propõem transformar os mapas em contra-dispositivos encontram-se a cartografia situacionista e a rizomática dos agenciamentos (GREGORI, 2020, p.154-7).

6 "Levantes" é o título de exposição organizada pelo filósofo e curador Georges Didi-Huberman e que esteve no Brasil entre outubro de 2017 e janeiro de 2018, no SESC. Um levante pode ser uma insurgência explícita, um ato de revolta, ou um gesto clandestino, um desejo de resistência sobrevivente em imagens de quem o praticou. $O$ ser humano se revolta, se insurge, sempre contra o que o oprime, o que o sujeita, por meio de invenções, expressões e assim se reinventa, renasce (LEVANTES, 2017). Levantar-se também remete ao processo arqueológico de escavar e descobrir camadas, objetos e informações silenciadas, de se fazer uma anamnese do passado (DIDI-HUBERMAN, 2017, p. 67), ação que também se refere ao trabalho do inconsciente humano no sentido de não apagar os vestígios do que não foi completamente esquecido, como afirma Didi-Huberman em entrevista a Vera Casa Nova (2016, s.p.).
} 
realizadas em percursos da autora pela cidade em $2020^{7}$, optou-se por fazer desse desafio a possibilidade de ampliação e debate, aprofundamento e desdobramento do plano com base em fotografias que, originadas de escolhas convertidas em gestos, estimulem a imaginação, expandindo-se para além de sua achatada bidimensionalidade. As imagens inserem-se em projeto denominado Cartografias do levante, proposta de sondagem imagética insurgente, inconformada, multiplicada em várias direções, com fortes contrastes, novas imagens e outras representações de territórios.

A iniciativa busca mapear movimentos e espaços repletos de atividades humanas atuais, exibindo complexidades, contradições, rachaduras e disputas de lugares e narrativas; elaboração, portanto, que não se faz somente sobre localidades e posições a serem conquistadas e anexadas em disputas bélicas, esvaziadas de sua indiscutível dimensão social, mas em sua profundidade espaço-temporal a envolver planos concretos e simbólicos, fluxos e paradas, memórias, imaginários e práticas que se configuram e reconfiguram dinâmica e dialeticamente.

\section{A CIDADE NA PANDEMIA: SINTOMAS E MEMÓRIAS INDESEJADAS}

Assentadas sobre camadas de passados, materialidades e ações humanas compõem a substância do espaço presente, a apontar para um porvir incerto, fundado em incongruências profundas, socialmente recalcadas, deformações e rasgaduras, nascidas de uma vocação para a revolta, às quais Didi-Huberman chama de sintomas (2020, p. 233-4 e 2011, p.72). Essas quebras da unidade e homogeneidade com que as vozes dominantes narram e representam o mundo seriam, portanto, desvios reveladores de verdades que não podem ser explicitadas porque implicariam transformações radicais, fraturas profundas nas fundações do sistema produtivo amalgamado pela ideologia e por culturas dominantes.

\footnotetext{
${ }^{7}$ Essas experiências fazem parte de investigação pós-doutoral mencionada na primeira nota, cujos resultados parciais foram publicados no número anterior da Revista ARA FAUUSP, em artigo da autora intitulado Cartografias do levante (2020, p. 145-170).
} 
A cidade é uma materialização possível do modo de produção, mas é na dimensão do lugar, ponto no qual as ações remotas e locais se encontram, que ela deixa ver as contradições e imperfeições desconsideradas e silenciadas pelas grandes narrativas e forças dominantes globais. A cidade e seus lugares, portanto, podem ser entendidos como acervos de memórias e ações, de representações de grupos diversos que compõem o tecido social desse espaço, articulação de materialidades e práticas humanas. Ou seja, é um patrimônio cultural de grande valor construído sobretudo mediante a circulação e conexão de pessoas e bens.

Mas o que ocorre quando interrompe-se, ainda que parcialmente, a circulação das pessoas? Como constituir uma memória coletiva da cidade que fale de sua complexidade no período da pandemia em que o funcionamento urbano ocorre fora da considerada normalidade, a radicalizar, invisivelmente, diferenças e exclusão? Teria o patrimônio cultural materializado na cidade se transformado em mero cenário no qual escancaram-se os sintomas da desigualdade e miséria? Como devolver os lugares ao olhar e trabalho da coletividade, recuperar os vínculos perdidos de modo que sua materialidade e seus usos constituam um patrimônio cultural valorizado, de constituição verdadeiramente cidadã?

As idas a campo e registros imagéticos de populações imensas invisibilizadas e tratadas como refugo são experiências de remontagem dessa cidade em tempo alterado, no qual sintomas crônicos pré-existentes mostram-se em sua versão aguda. Procura-se sair do clichê da cidade produtiva e pujante e aproveitar a oportunidade de se recolocar uma questão crucial sobre como alterar essa memória coletiva, que segue reprimindo seus traumas e regurgitando seus recalques, a fim de vislumbrar horizontes futuros mais amplos, nascidos dessa fissura incômoda que interrompe a linearidade e a homogeneidade de todas as coisas.

Admite-se, como afirma Maurice Halbwachs, que a memória individual pertence à coletiva porque pensa-se coletivamente a partir de noções e códigos comuns a diferentes agrupamentos. A memória individual, portanto, ao invés de contrapor-se à coletiva, se articula a outras memórias particulares para compô-la, é parte de uma construção comum que prescinde da presença simultânea de todos os envolvidos, já 
que o coletivo acompanha os indivíduos em pensamento (1990, p. 34, 51). Enquanto construção humana, a memória sofre transformações históricas, alterando sua função a cada tempo. Nesse sentido, como afirma Jacques Le Goff (1990, p. 368), não é única ou imutável, mas uma construção social contextualizada. Diante de tal concepção, as imagens aqui exibidas procuram colaborar para a constituição de uma memória coletiva transformável e remontada.

Não é sem grande espanto que se observam vários pontos históricos de São Paulo ocupados por centenas de pessoas sem moradia enquanto lugares da boemia paulistana são recentemente invadidos por aqueles que decidiram não mais ficar em casa, cansados da repetição doméstica cotidiana e da falta de encontro com amigos e familiares, saindo para consumir a cidade, muitos sem máscaras e se aglomerando, nas calçadas de bares da Vila Madalena, bairro conhecido por sua aura criativa ${ }^{8}$, ou nos shoppings paulistanos.

Evidências cabais de uma engrenagem engendrada pela humanidade que exclui parcela significativa da sua própria espécie como se isso fosse natural, que trata a coletividade apenas como promessa de consumo e prazer imediato. Não existe foco ou embelezamento concebível, mas empalidecimentos. Há o tremor angustiado, o olhar disperso e o ofuscar da luz dos registros mostram instantes e fragmentos do que é impossível ser imaginado e, ao mesmo tempo, faz-se indispensável ser reconhecido.

\footnotetext{
${ }^{8}$ Valor simbólico atribuído ao território que incrementa o preço dos terrenos, encarece aluguéis e produtos, atraindo grande número de pessoas para consumir artigos diferentes dos comercializados para a massa. O lugar torna-se, assim, objeto mercantilizado e tem de se reinventar para continuar atrativo, inevitavelmente curvando-se à massificação, como apontam os princípios da destruição criativa de Schumpeter (1943).
} 


\section{IMAGENS EM MOVIMENTO: REPRESENTAÇÕES DOS SINTOMAS, EXPERIÊNCIAS DE IMAGINAÇÃO}

De acordo com Didi-Huberman, imagens oferecem a quem as olha uma sensação de paradoxo (2013, p.9). O que parece deixar tudo evidente e distinto, na verdade, resulta de uma ação mediada que aparentemente se mostra em totalidade, mas, paradoxalmente, oculta, de tal forma que o espectador sabe e não-sabe de tudo. Em outras palavras, estabelece-se uma situação que aniquila os pensamentos totalizantes e fechamentos unívocos, monolíticos, edulcorados. É nesse obscurecimento, interstício entre saber e não-saber, que são abertas fendas para o conhecimento e para a transformação de narrativas e interpretações.

A forma da imagem, sua apresentabilidade, se desdobra enquanto fragmento, como representação parcial e perspectiva de novos entendimentos e novas montagens (DIDI-HUBERMAN, 2020, p. 16). Compreendidas em consonância com Didi-Huberman como intenções, atos de resistência e testemunhos (2004, p. 60-72), imagens adquirem, nessa acepção, um sentido político inefável, que se procurou investigar nas experiências fotográficas publicadas.

A partir de formulações de Didi-Huberman pode-se dizer que o gesto gerador das imagens propicia um imaginar configurado como um ato de resistência enquanto continuidade do ato original da criação imagética. Trata-se de ensejo de refutação do inimaginável e de uma inscrição na história enquanto memória; de sobrevivência e de redenção da humanidade, portanto. As imagens são o que deixam ver, mas ultrapassam essa condição no gesto político da explicitação do que não pode ser visto, do que não se pode admitir.

Nesse cenário, a montagem aparece como um recurso para superar a narrativa linear e ordenada, para apresentar anacronismos, sobrevivências e resistências. A montagem contextualiza, forma testemunhos e apresenta as complexidades do tempo, seus estratos arqueológicos e profundidades. Segundo Didi-Huberman em entrevista a Vera Casa Nova (2016, s.p.) ela é "uma experimentação de pensamento sensível" que, ao criar relações e sentidos diversos, pode desconstruir, desmontar clichês e estereótipos, estimular a imaginação e o conhecer. De tal modo, a memória 
elaborada por meio de montagens vai além da fria listagem de objetos. Ela viabiliza uma anamnese do passado para se compreender o presente, abre a fresta para a narração dos traumas a fim de que sejam superados e não repetidos (DIDIHUBERMAN, 2019, p. 61, 67).

A imaginação, prática que envolve o desdobramento da imagem via recepção, é um convite a desconfiar, conhecer mais, a trabalhar com esse inimaginável que se busca esconder. É descobrir as camadas das quais a imagem é aparição, rastro, vestígio, sintoma. Trata-se de entender a imagem, tal como coloca Didi-Huberman, como esse objeto impreciso, incompleto, inadequado $(2004$, p.59) que, entretanto, tem a enorme potência de revelar friç̧ões, recalques e frestas, faixa em que se colocam as experiências do pós-doutorado e do artigo.

Feitas a partir de aparatos fotográficos, câmeras ou celulares, na proteção de um automóvel em movimento, as imagens apresentadas evidenciam, no enquadramento oblíquo, no borrão cinético e na falta de foco, a urgência e o assombro diante das aparições sociais que se materializam nas práticas e espaços da cidade, fraturas expostas a observadores minimamente atentos e aprofundadas pelo isolamento social e pequeno apoio do Estado a parte das pessoas vulneráveis $^{9}$. Também se revela a proibição do toque, a separação dos estratos sociais que a transparência não consegue superar e a necessidade da denúncia e da restituição, da recolocação das coisas fora de sua sacralidade, objetos subtraídos e fixados fora do uso do comum por poderes dominantes (AGAMBEN, 2007, p. 58), e do lugar comum, para se situar no lugar do comum, inseridas na comunidade, na prática coletiva (DIDI-HUBERMAN, 2017b, p. 223).

\footnotetext{
${ }^{9}$ Após pressão do congresso, o governo federal decidiu implementar um auxílio-emergencial no valor de $\mathrm{R} \$ 200,00$ mensais por 3 meses durante a pandemia. O poder legislativo aumentou o valor para $\mathrm{R} \$ 600,00$, após Projeto de Lei da oposição que foi aprovado pela Câmara e pelo Senado e sancionado pelo presidente no dia 1 을 de abril. Apesar de equivaler a menos de $60 \%$ do valor do salário mínimo atual e não estar disponível a todas as pessoas, o auxílio-emergencial foi responsável por manter a sobrevivência de milhões de brasileiros e será prorrogado, com valor de $R \$ 300,00$, até o final de 2020.
} 
Circular por São Paulo durante o limitado confinamento ${ }^{10}$ que houve na cidade é emudecer diante da triste constatação da barbaridade engendrada pela suposta racionalidade técnica que o desenvolvimento tecnológico enaltece. Ou, nas palavras de Walter Benjamin (1987, p. 115), do "monstruoso desenvolvimento da técnica, sobrepondo-se ao homem", ao qual juntam-se o individualismo, a competitividade e a intolerância, processo no qual foram abandonadas, "uma depois da outra todas as peças do patrimônio humano" (p. 114-5) ${ }^{11}$, uma miséria que é tanto a pobreza da falta de recursos mínimos para sobreviver quanto a pobreza de experiências a que a humanidade está submetida, exclusivamente voltadas para o consumo e o imediatismo, e, assim, a miséria da própria condição humana na atualidade.

É necessário resgatar essas peças e restituí-las ao debate e engajamento públicos, sob pena de não mais podermos nos reconhecer enquanto humanidade. Uma retomada que opera nas fissuras por onde emergem os sintomas, a indigência existente, mas que não se quer ver, falhas atribuídas a incompetências individuais, responsabilidade e pobreza, pertencentes, entretanto, a todos nós ${ }^{12}$.

\footnotetext{
${ }^{10}$ Segundo o Governo do Estado, a taxa de isolamento ideal para conter a disseminação do Sars-Cov2 é de $70 \%$. Na cidade de São Paulo o pico foi de 59\%, nos dias 29 de março e 5 de abril (domingos). No dia 8 de agosto, também um domingo esse número caiu para $48 \%$. Em nenhum momento a porcentagem de $70 \%$ foi atingida.

Fonte: https://www.saopaulo.sp.gov.br/coronavirus/isolamento/. Acesso em: 10 ago. 2020.

${ }^{11}$ Ao se referir à Primeira Grande Guerra, em texto publicado originalmente em 1933, Walter Benjamin $\left(1987\left(^{* *}\right)\right.$ fala de uma "geração que [...] viveu uma das mais terríveis experiências da história" eloquentemente percebida no silêncio dos combatentes regressados de uma guerra violenta praticada sobretudo em trincheiras nas quais a morte se dava pelas mãos de cada um dos indivíduos, "mais pobres em experiências comunicáveis, e não mais ricos". Para o filósofo alemão, as vivências da guerra, da inflação e da fome seriam criadoras de "uma nova forma de miséria", porque resultantes do "monstruoso desenvolvimento da técnica, sobrepondo-se ao homem", um processo no qual "abandonamos uma depois da outra todas as peças do patrimônio humano" em troca do atual" (p. 114-5).

${ }^{12}$ Em Noite e neblina (Noite e neblina, no Brasil), filme sobre os campos de extermínios nazistas dirigido por Alain Resnais (1955), o narrador pergunta, diante da esquiva dos envolvidos na morte de milhões de judeus e outros "dispensáveis", o narrador pergunta para o espectador: "Então, quem é responsável?" [...] "quem de nós está vigiando desse estranho observatório para nos alertar sobre a vinda de novos executores? São suas faces realmente diferentes das nossas?" As questões podem ser trazidas para a atualidade, mas a resposta provavelmente incluirá a todos. Em maior ou menor medida, somos todos agentes da exclusão e da miséria, desavisados para a execução que já chegou e passa por nossas próprias mãos.
} 
Nessa experiência, foi preciso olhar para baixo, para onde vidas e corpos se deitam, se derramam entre papelões, sacos de lixo, cobertores, barracas ${ }^{13}$; procurar no solo da cidade, esse lugar frequentemente desconsiderado, aquilo que não se deseja ver ou reconhecer.

Apesar de penosa - porque implica reconstituir um tecido humano esgarçado, no qual a humanidade possa existir como algo universal, com múltiplas nuances culturais, em contraposição ao pensamento binário violento e deletério dominante, que apaga qualquer chance de convivência ou solidariedade -, ela é a fresta por onde pode entrar a luz de um novo arranjo em que esse tipo de fratura não seja natural ou tolerável e muito menos um vício envergonhado, recalcado, que aflora como ato falho em pleno coração cidade, resistindo silenciosamente, à espera de ser visto e cuidado.

A restituição, o resgate, das imagens à esfera pública, em período no qual tudo tem se passado - e durante a pandemia ainda mais agudamente - de espaço privado para espaço privado, substituindo-se inteiramente a realidade pela virtualidade, pela mediação da tela dos dispositivos eletrônicos disponíveis a certas camadas socioeconômicas, consiste em mostrar o que foi censurado, calado ou esquecido, o que se considera resto, refugo e retorná-lo a quem é de direito, ou seja, "à comunidade, aos cidadãos" (DIDI-HUBERMAN, 2017, p. 206), em que pese o fato de que essa devolução tenha sido evitada por estratégias sutis de dominação das mentalidades e de manipulação dos desejos.

O crescente apagamento de seres humanos tem origem em uma invisibilidade social meticulosamente imposta a grupos de modo a esconder as coisas que o poder dominante considera inoportuno, entre elas a miséria e resíduos do modo de

\footnotetext{
${ }^{13}$ Segundo dados da ONU publicados em reportagem de Rodrigo Bertolotto (2020), o Brasil é o sexto país mais desigual do mundo, em ranking liderado por cinco representantes do continente africano: África do Sul, Namíbia, Zâmbia, República Centro-Africana e Lesoto e seguido por outros quatro também africanos. A desigualdade que sempre foi marcante no país, se acentuou durante a pandemia, é o que mostra reportagem de Marina Rossi, do El País (2020). Milhões de pessoas ficaram sem comer durante o isolamento para combate à pandemia segundo dados de pesquisa do Ibope e da Unicef, e quando se alimentaram, tiveram à sua disposição comida da pior qualidade. Realizada por telefone em julho de 2020, a pesquisa acessou os que ainda têm casa e podem comer alguma coisa. Paralelamente, os 42 bilionários nacionais acumularam mais dinheiro em suas contas entre março e julho de 2020 (BERTOLOTTO, 2020, s.p.).
} 
produção - sistema que se reproduz apesar e acima das pessoas. Socialmente construída, essa cegueira exclui ou condena o que não se quer/pode ver, e se acentua no confinamento da quarentena. Olhar as imagens tiradas em campo e trabalhar com o incômodo da visão fragmentada de algo que nos constitui, mesmo na impossibilidade de aceitação, é uma prática dura, mas necessária.

Walter Benjamin (1987 p. 114) denuncia a incapacidade de experiência da humanidade na Era Contemporânea a partir das traumáticas e emudecedoras vivências da Primeira Guerra Mundial em momento que uma nova guerra estava em gestação. Em diálogo com Benjamin, o filósofo Giorgio Agamben afirma, no entanto, que não é necessária uma catástrofe como a guerra para destruir a possibilidade de passar por vivências significativas. A "pacífica existência cotidiana em uma grande cidade é, para este fim, perfeitamente suficiente" (2008, p. 21).

Na esteira de Benjamin e Didi-Huberman, o pedagogo Jorge Larrosa Bondía (2002, p. 25-6) considera a experiência como algo que atravessa o sujeito que a vivencia, um espaço estranho e perigoso no qual encontram-se oportunidades de saberes desconhecidos, incontroláveis e singulares que fazem a mediação entre o conhecimento e a vida humana.

Longe de testes objetivos e controlados com a lente da câmera, as fotografias feitas no âmbito da pesquisa apontam para uma ampliação de saberes, miram em direção à inexatidão dos testemunhos parciais, mas imprescindíveis. São gestos de denúncia, levantes e insurgências contra o estado naturalizado de estruturas apodrecidas e rachadas que produzem miséria, exclusão e apagamentos. 

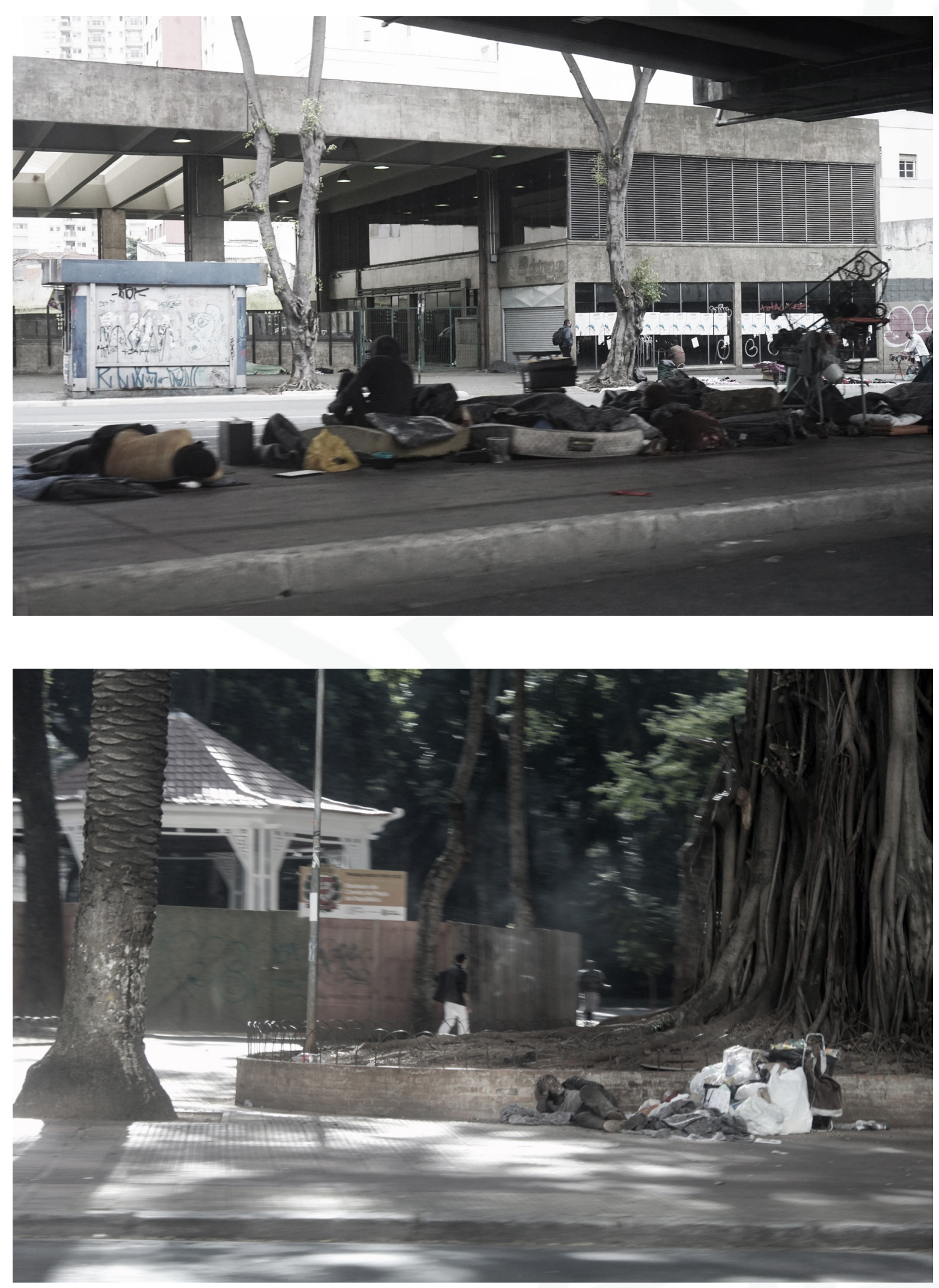

Em cima, Rua Amaral Gurgel, 25 Agosto 2020; embaixo, Praça da República, 18 Julho 2020. Fotos da autora. 

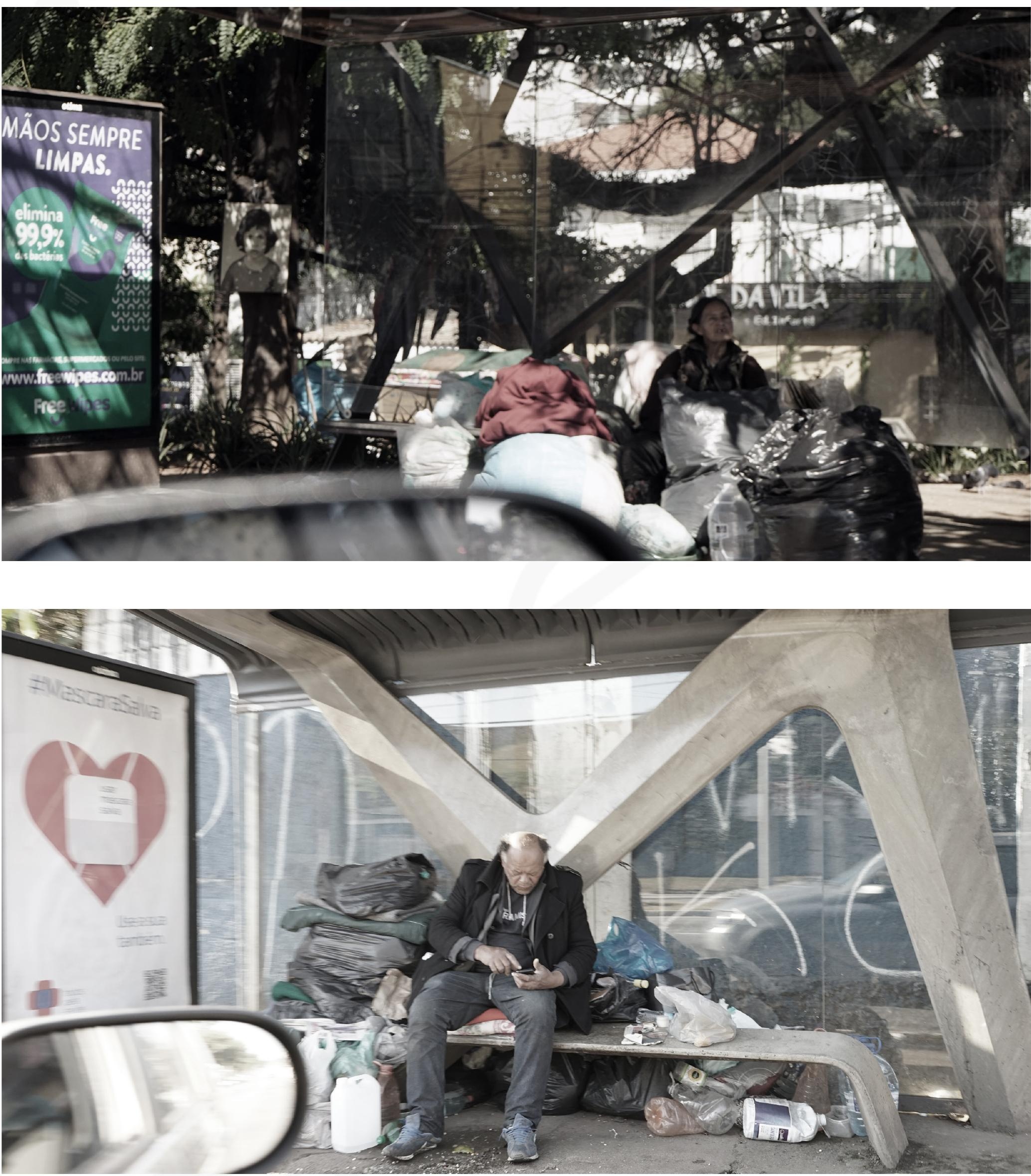

Em cima, Rua Heitor Penteado, 12 Julho 2020; embaixo, Av. dos Bandeirantes, 10 Maio 2020.

Fotos da autora. 

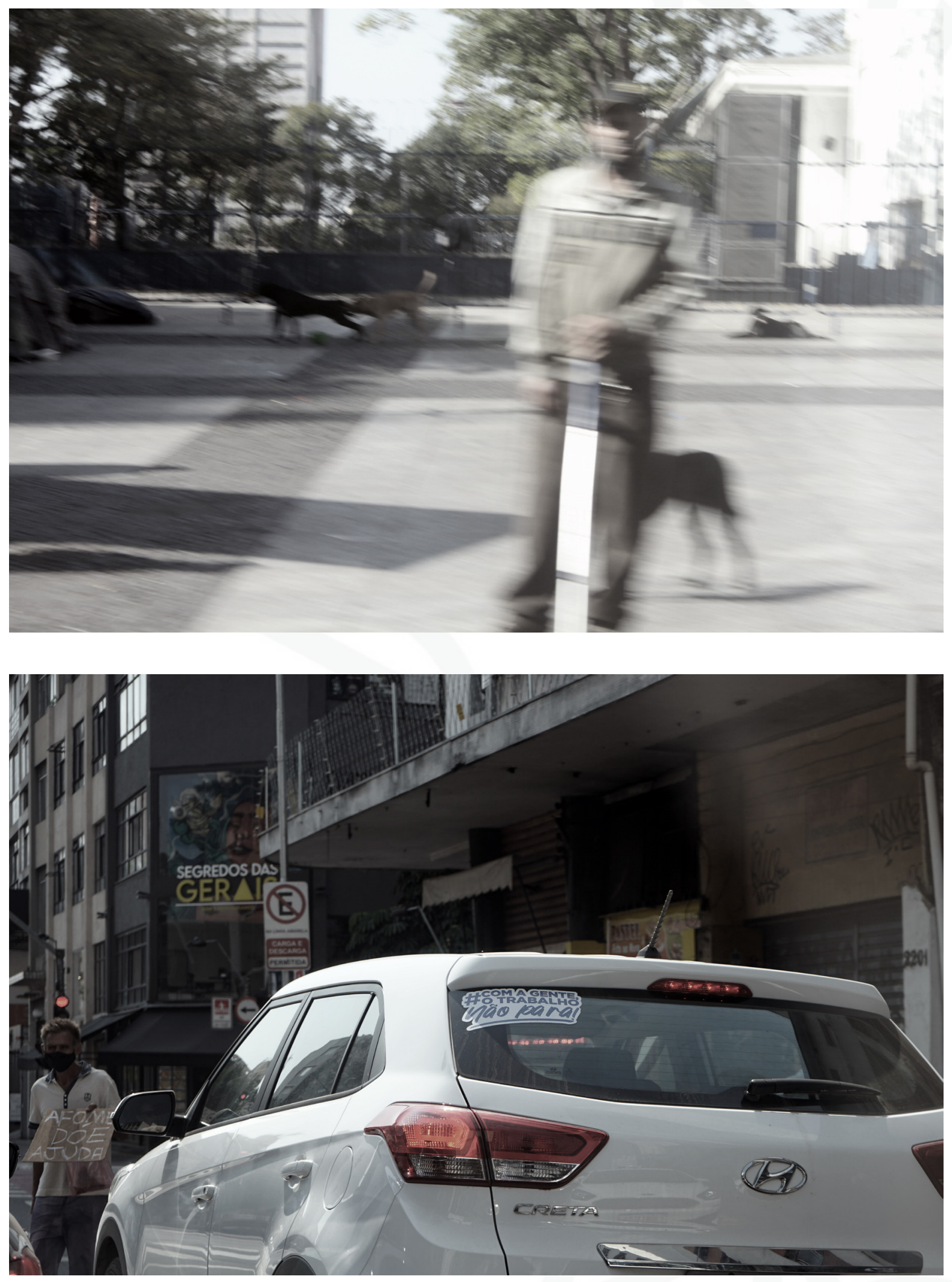

Em cima, Pátio do Colégio, 18 Julho 2020; embaixo, Rua da Consolação, 14 Setembro 2020.

Fotos da autora. 

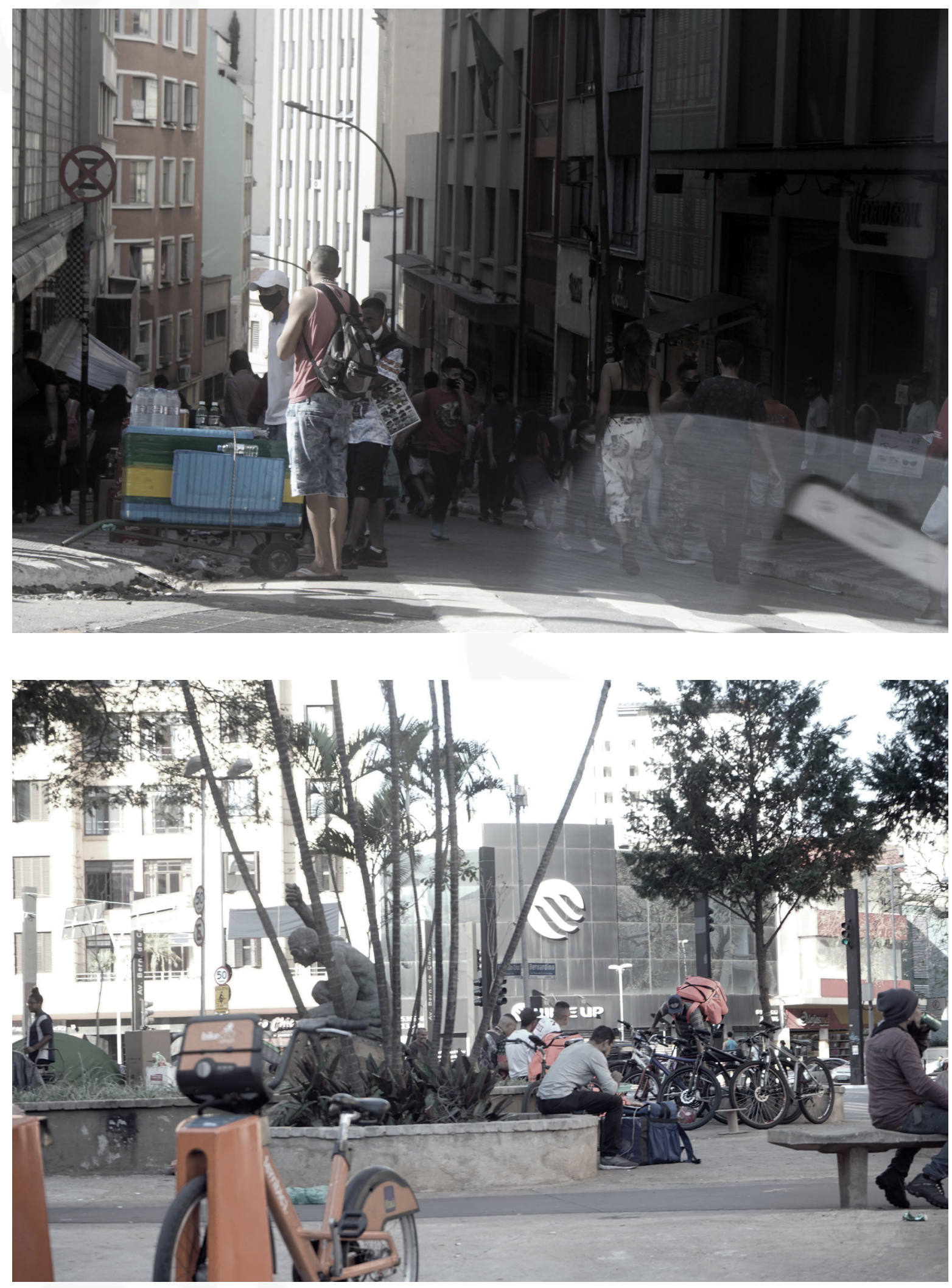

Em cima, Ladeira Porto Geral, 18 Julho 2020; embaixo, Av. Paulista, 29 Agosto 2020.

Fotos da autora. 

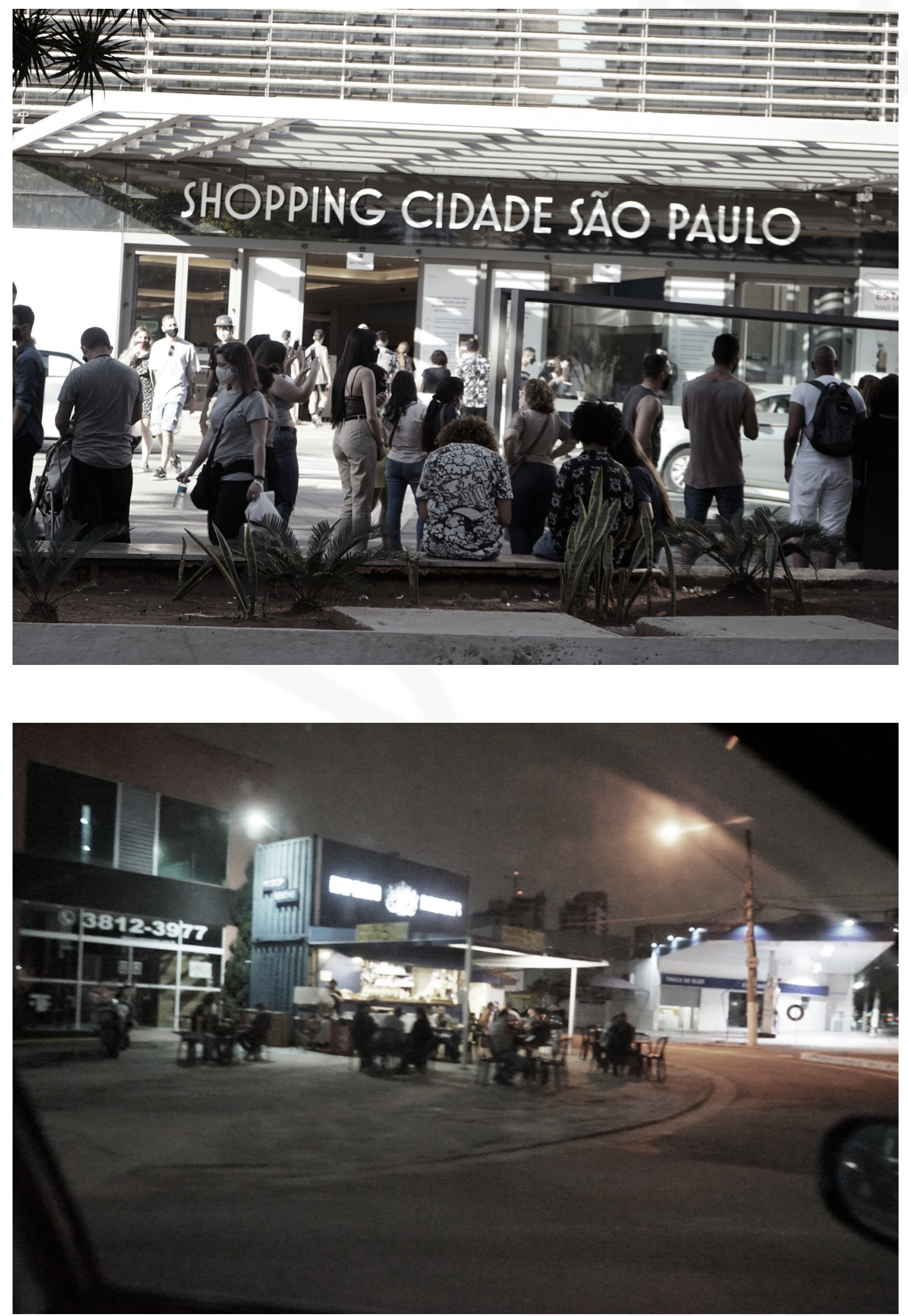

Em cima, Av. Paulista, 29 Agosto 2020; embaixo, Rua Alvarenga, 15 Setembro 2020.

Fotos da autora. 

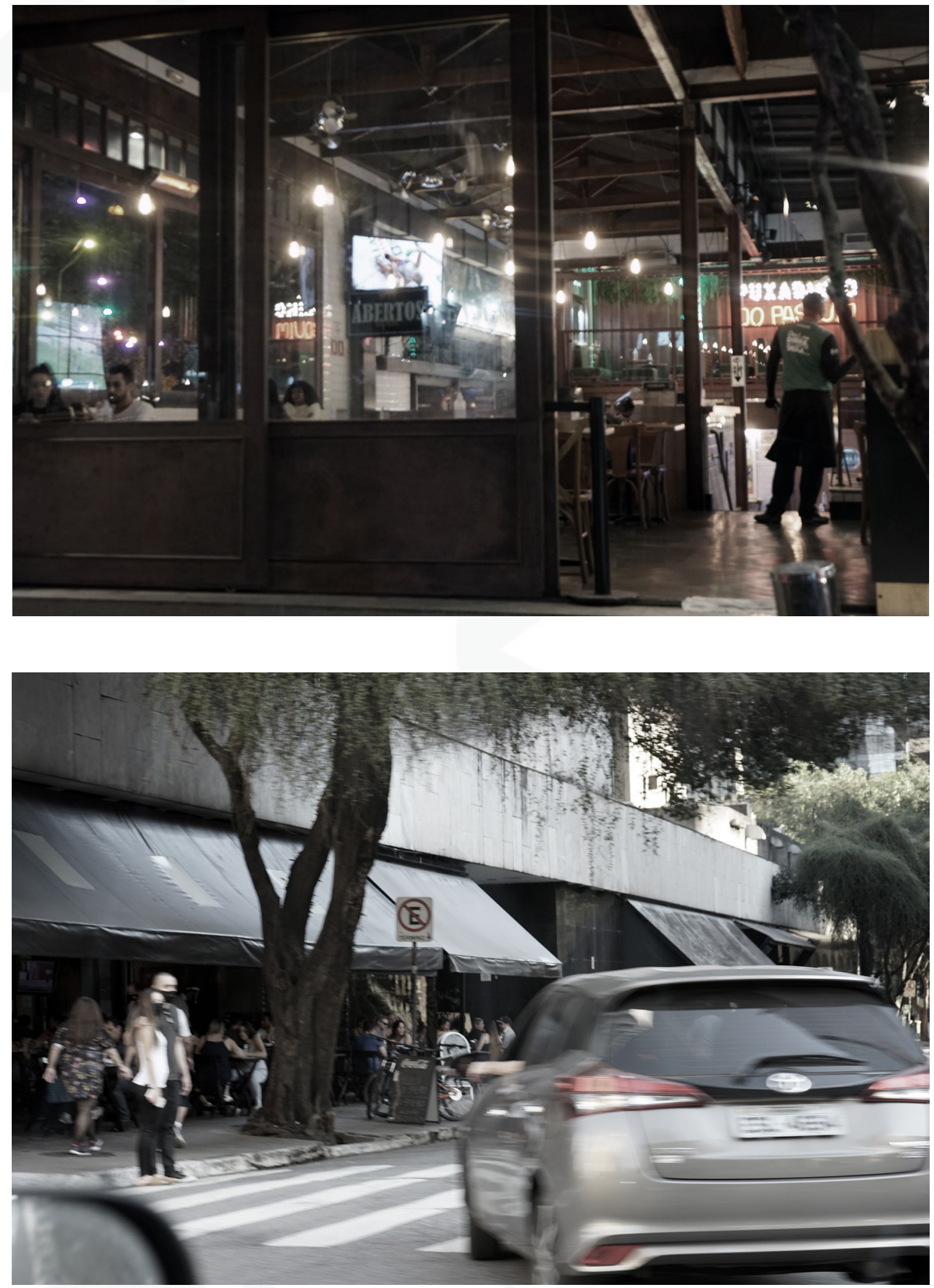

Em cima, Rua Fradique Coutinho, 15 Setembro 2020; embaixo, Av. Paulista, 29 Agosto 2020.

Fotos da autora. 

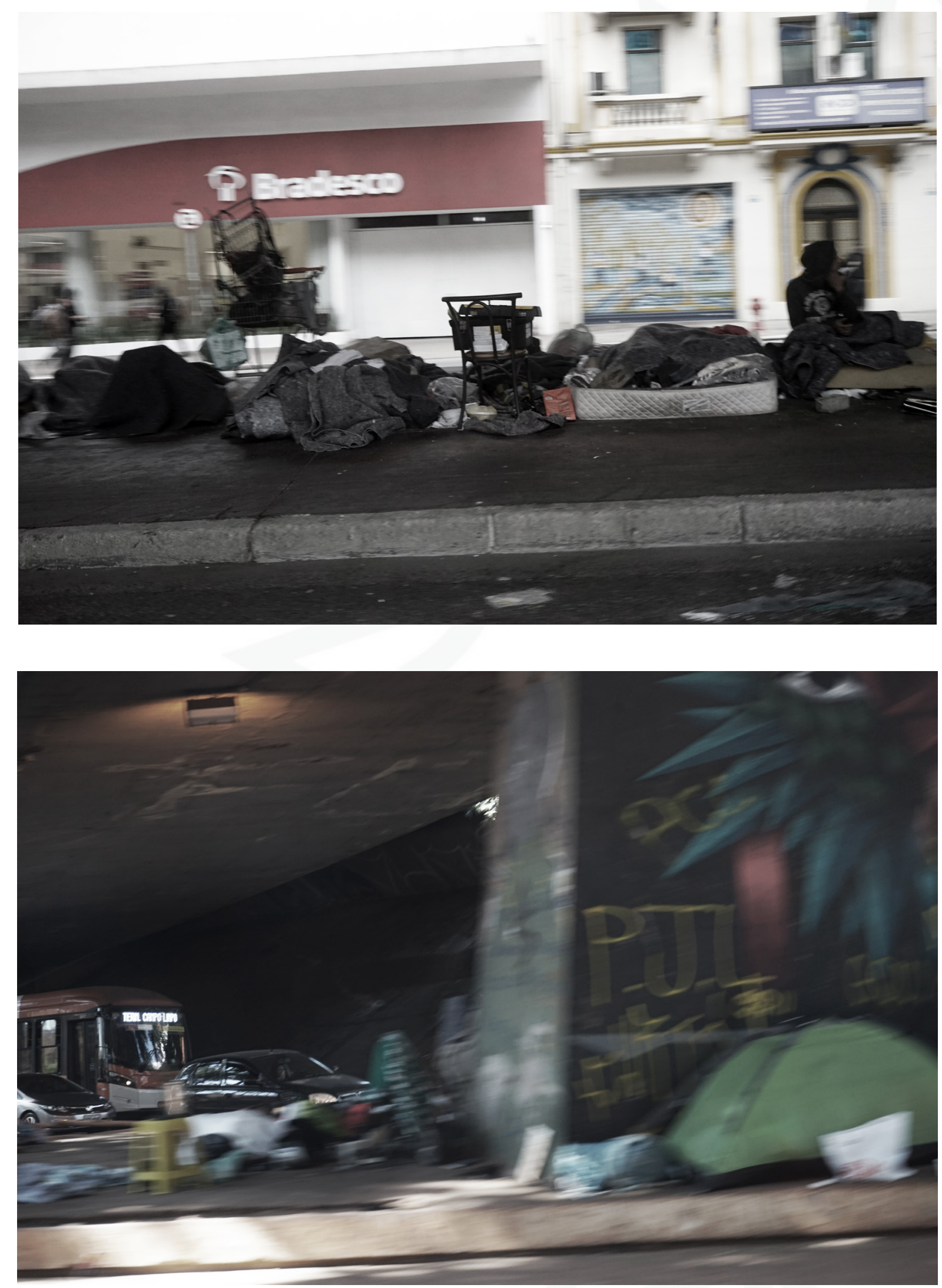

Em cima, Rua Amaral Gurgel, 25 Agosto 2020; embaixo, Av. Rebouças, 29 Agosto 2020.

Fotos da autora. 

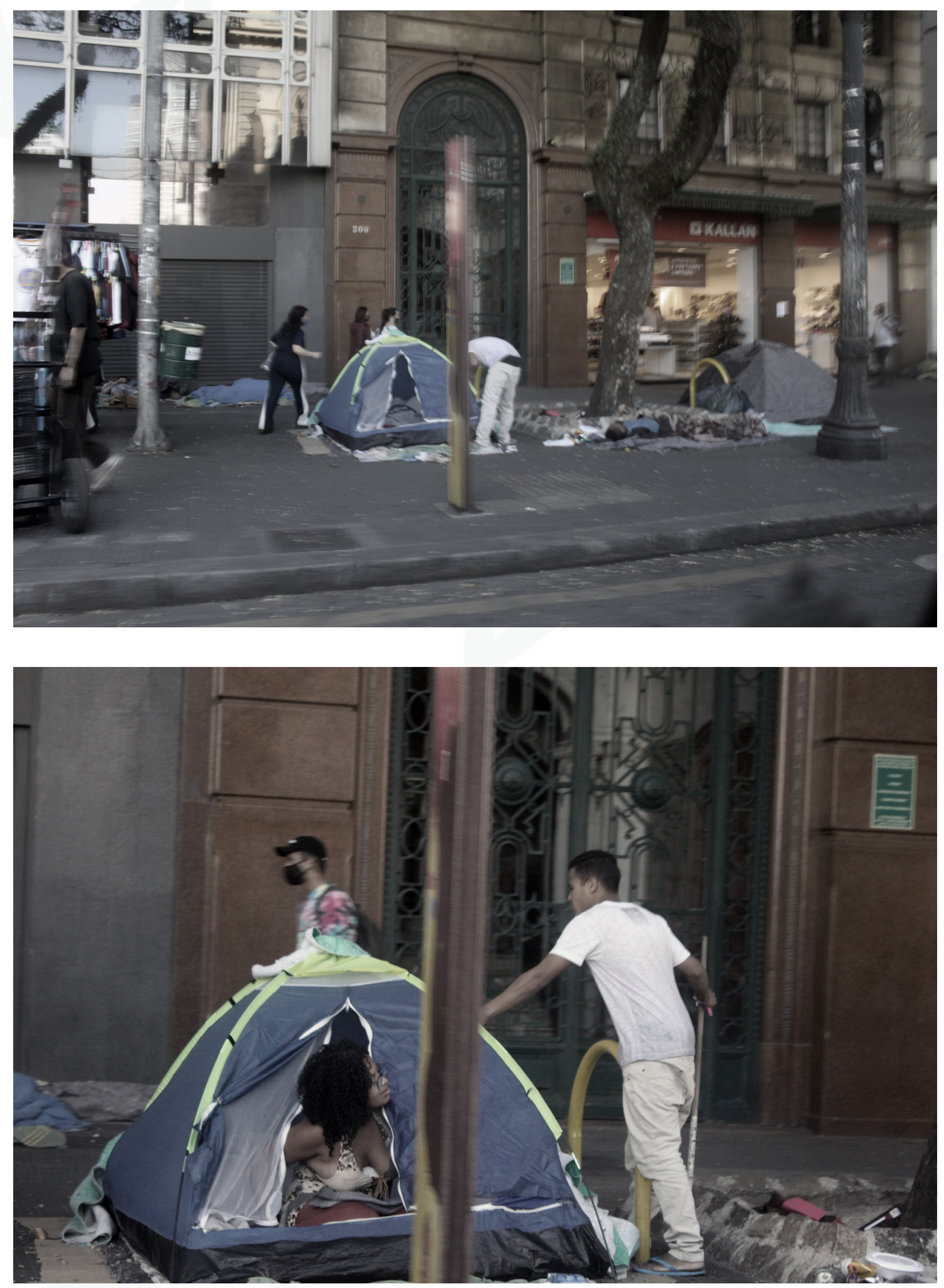

Praça Ramos de Azevedo, 18 Julho 2020. Fotos da autora. 

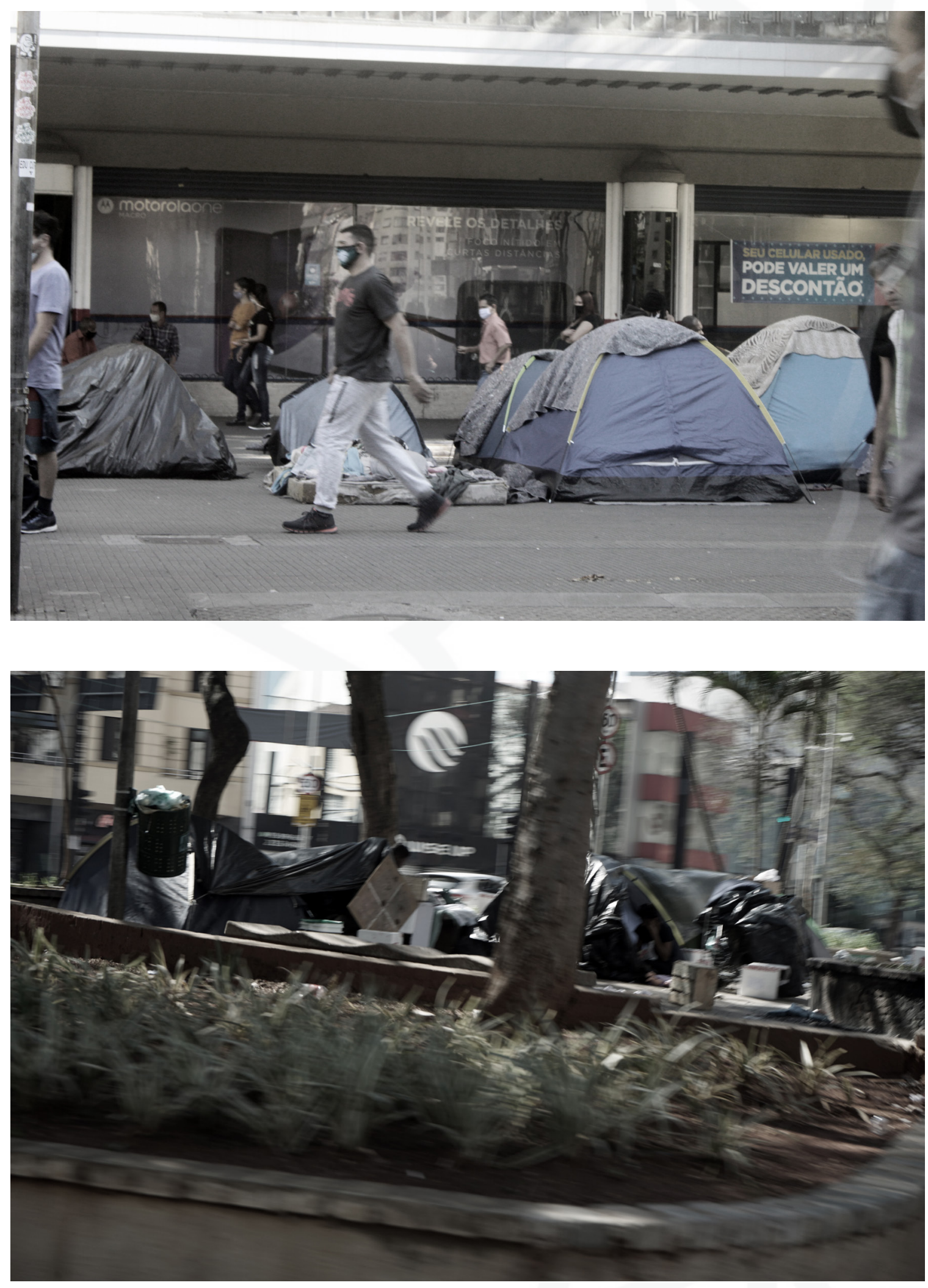

Em cima, Praça Ramos de Azevedo, 18 Julho 2020;; embaixo, Av. Paulista, 29 Agosto 2020.

Fotos da autora. 

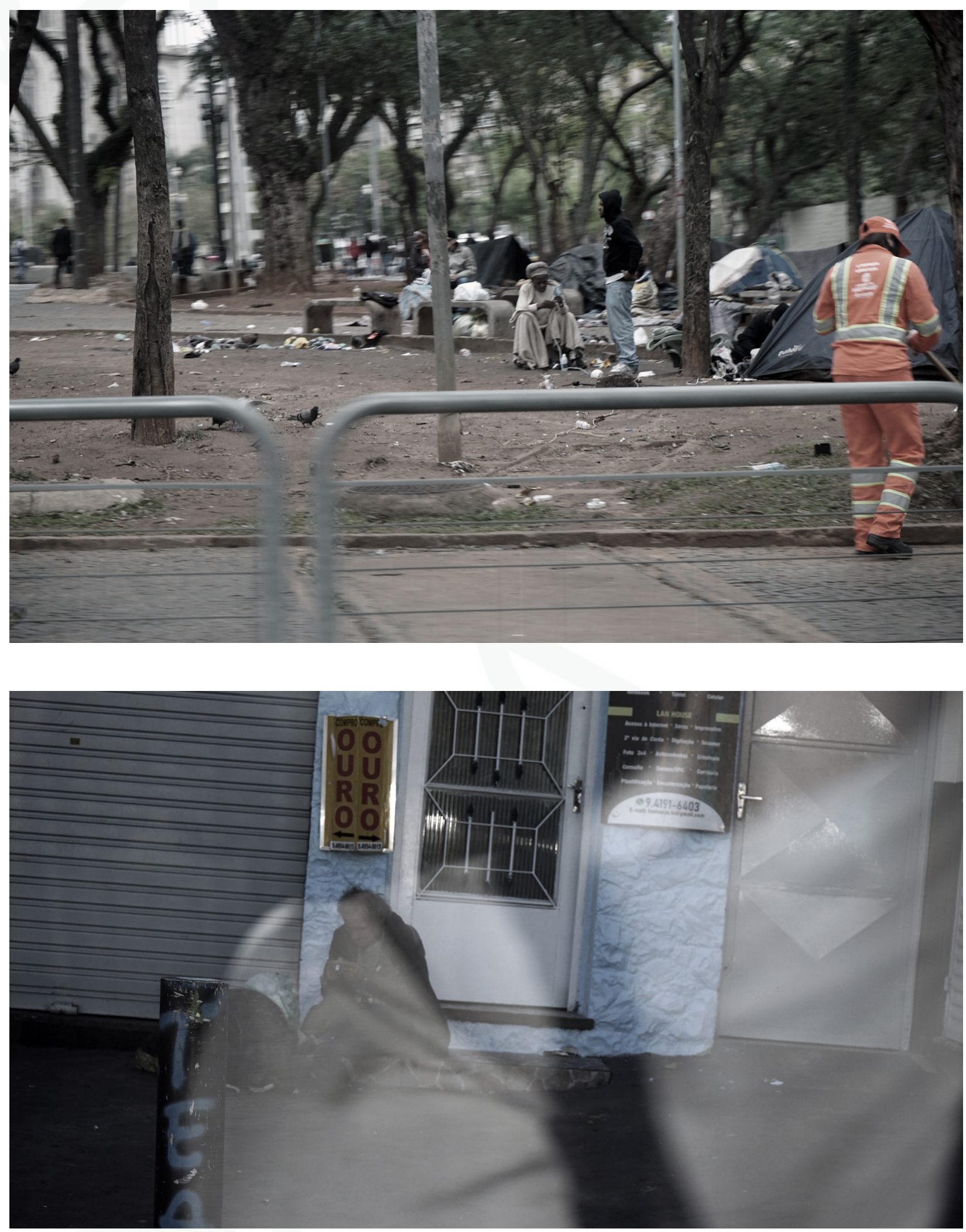

Em cima, Praça da Sé, 25 Agosto 2020; embaixo, Rua Cayowaá, 12 Julho 2020.

Fotos da autora. 

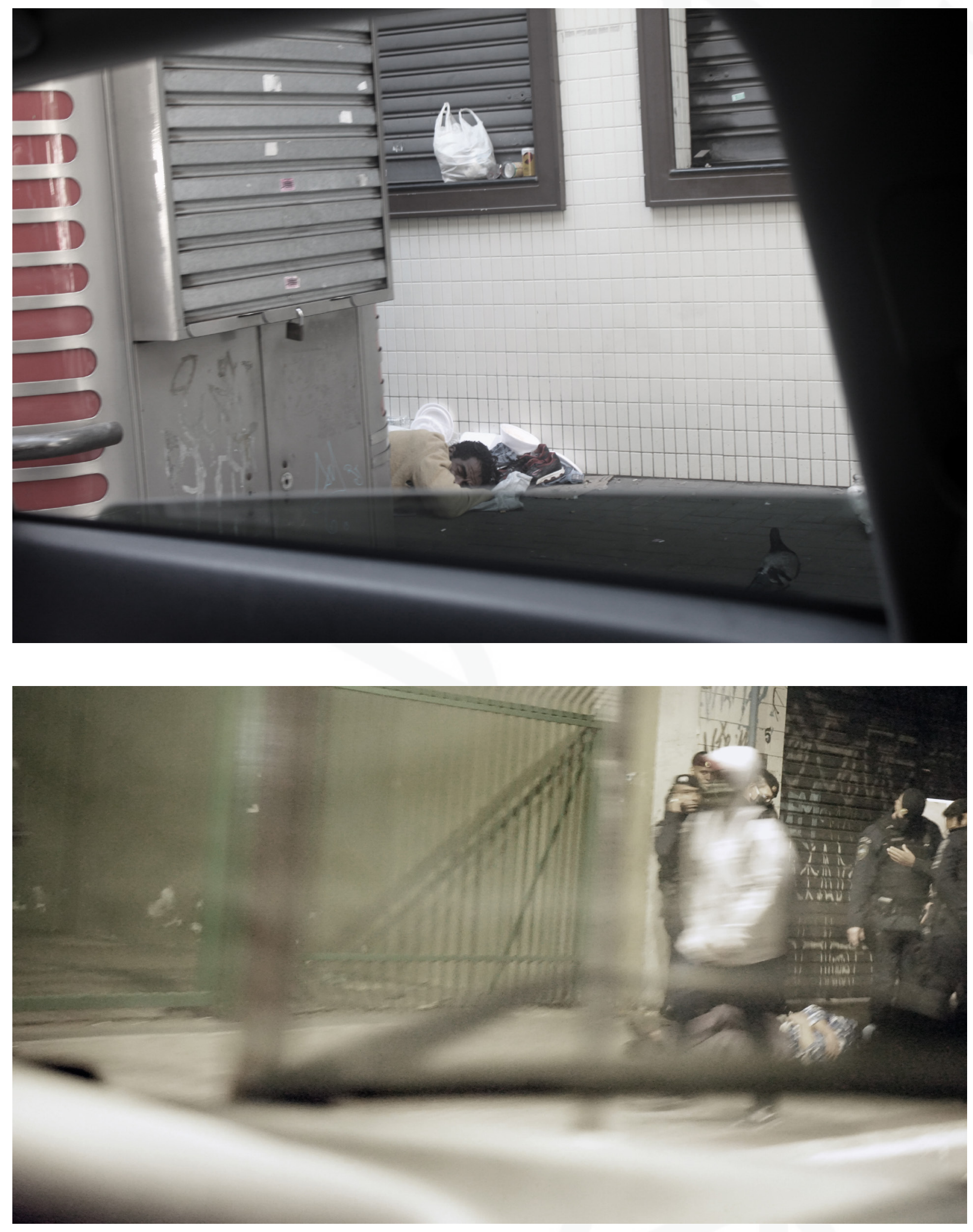

Em cima, Rua Luis Coelho, 18 Julho 2020; embaixo, Estação da Luz, 15 Julho 2020.

Fotos da autora. 

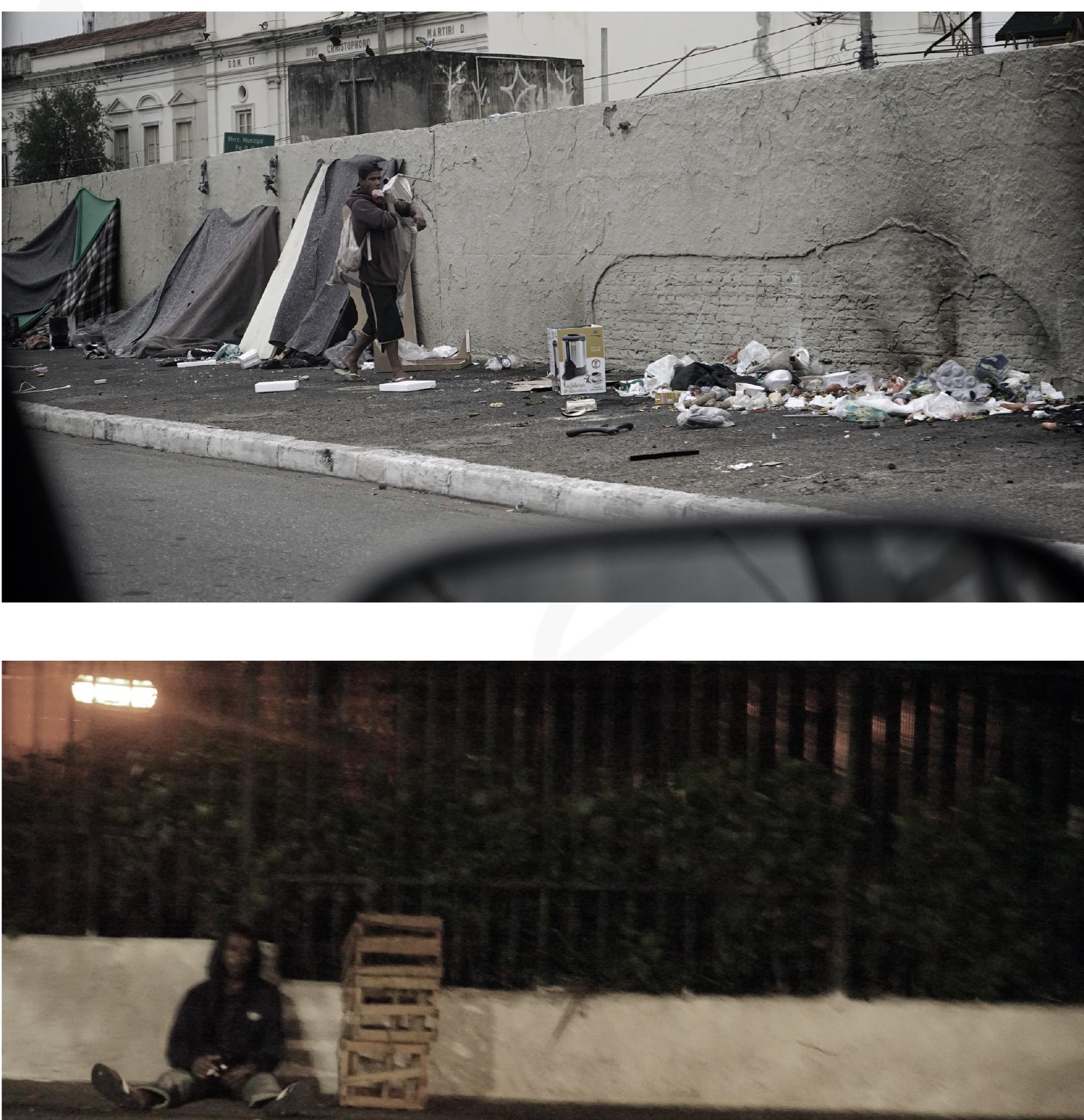

Av. Tiradentes, 15 Julho 2020. Fotos da autora. 

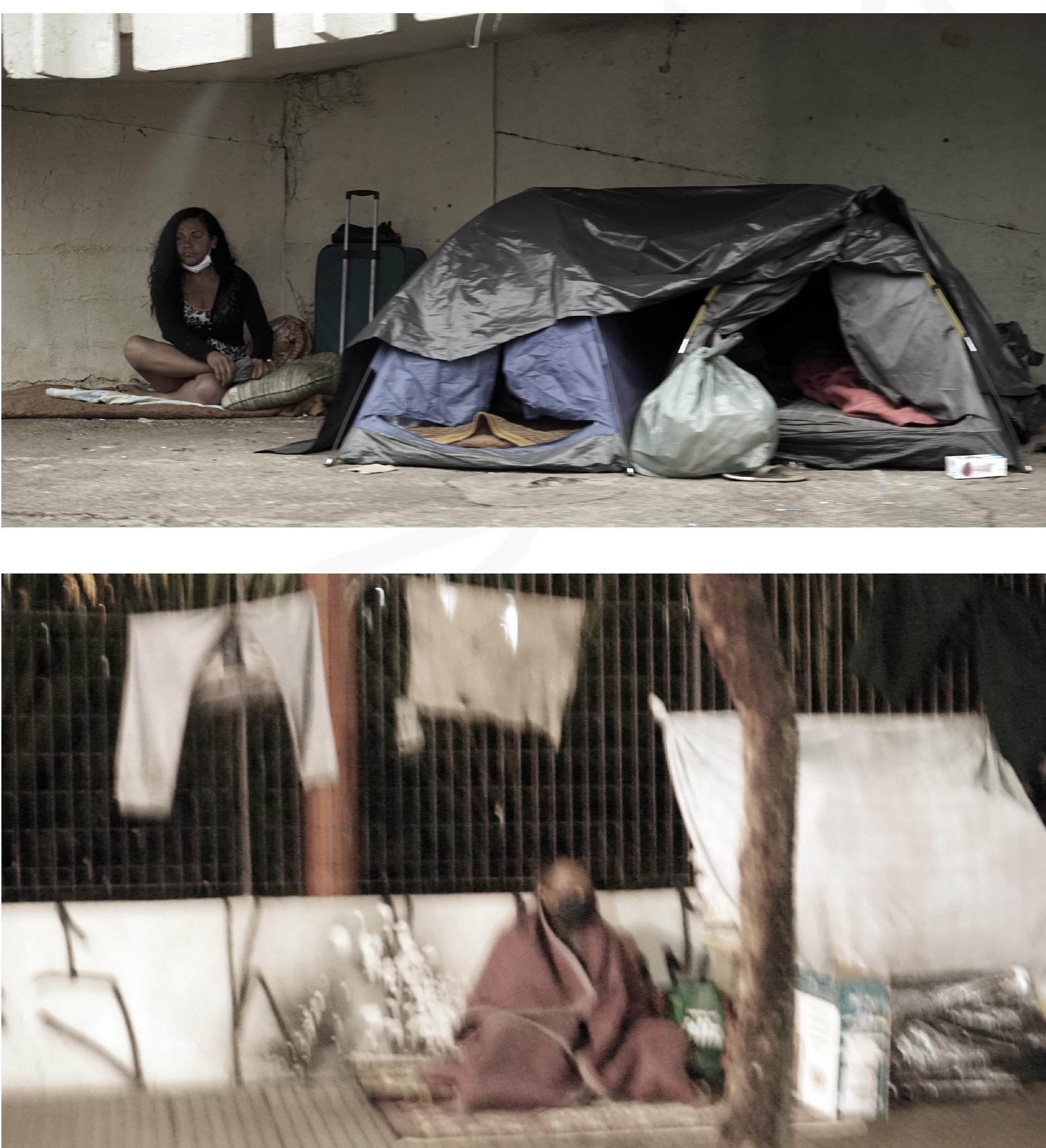

Em cima, Av. Tiradentes, 15 Julho 2020; embaixo, Av. Rebouças, 15 Julho 2020. Fotos da autora. 

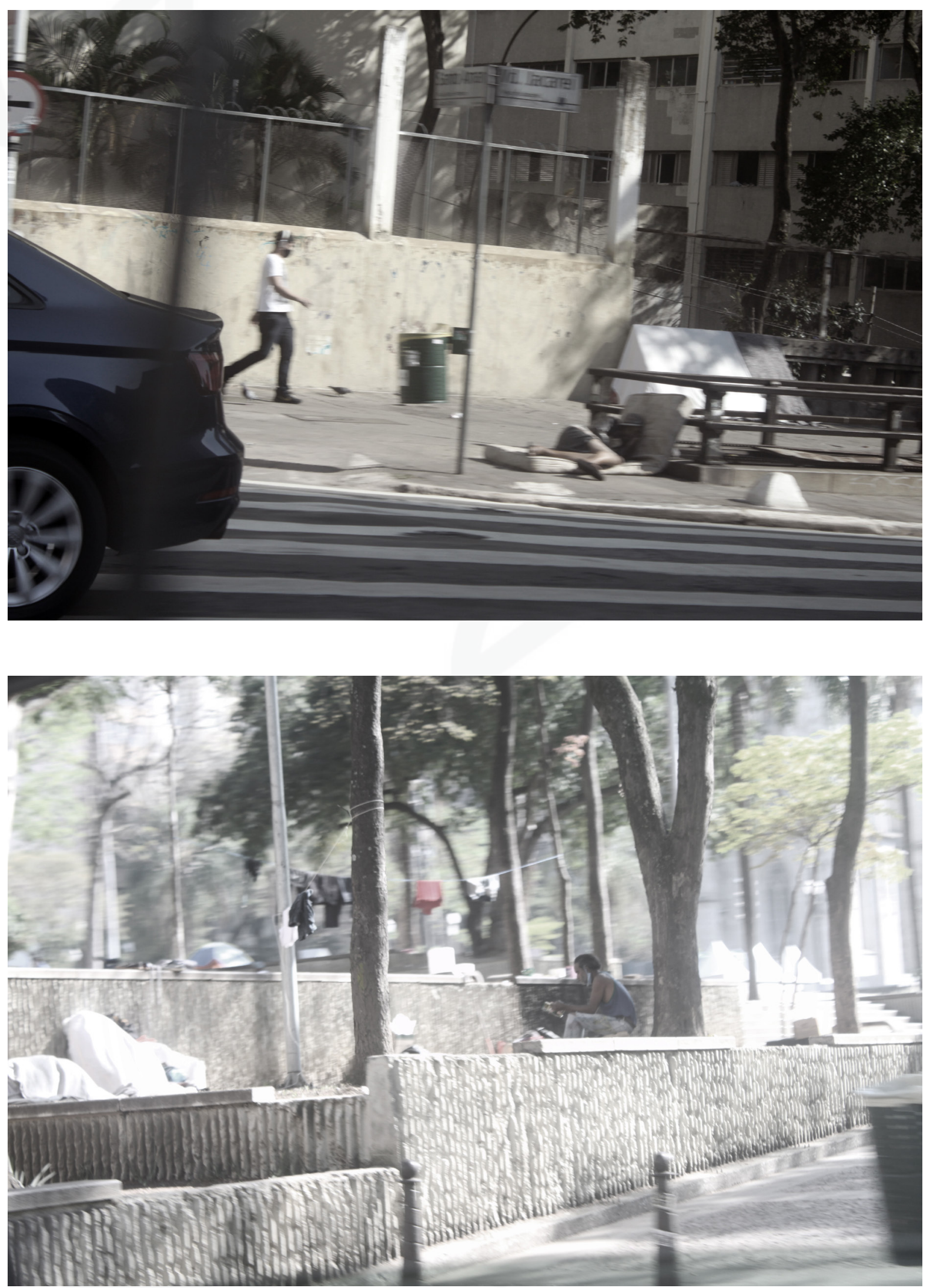

Em cima, Viaduto Jacareí, 18 Julho 2020; embaixo, Praça da Sé, 18 Julho 2020.

Fotos da autora. 

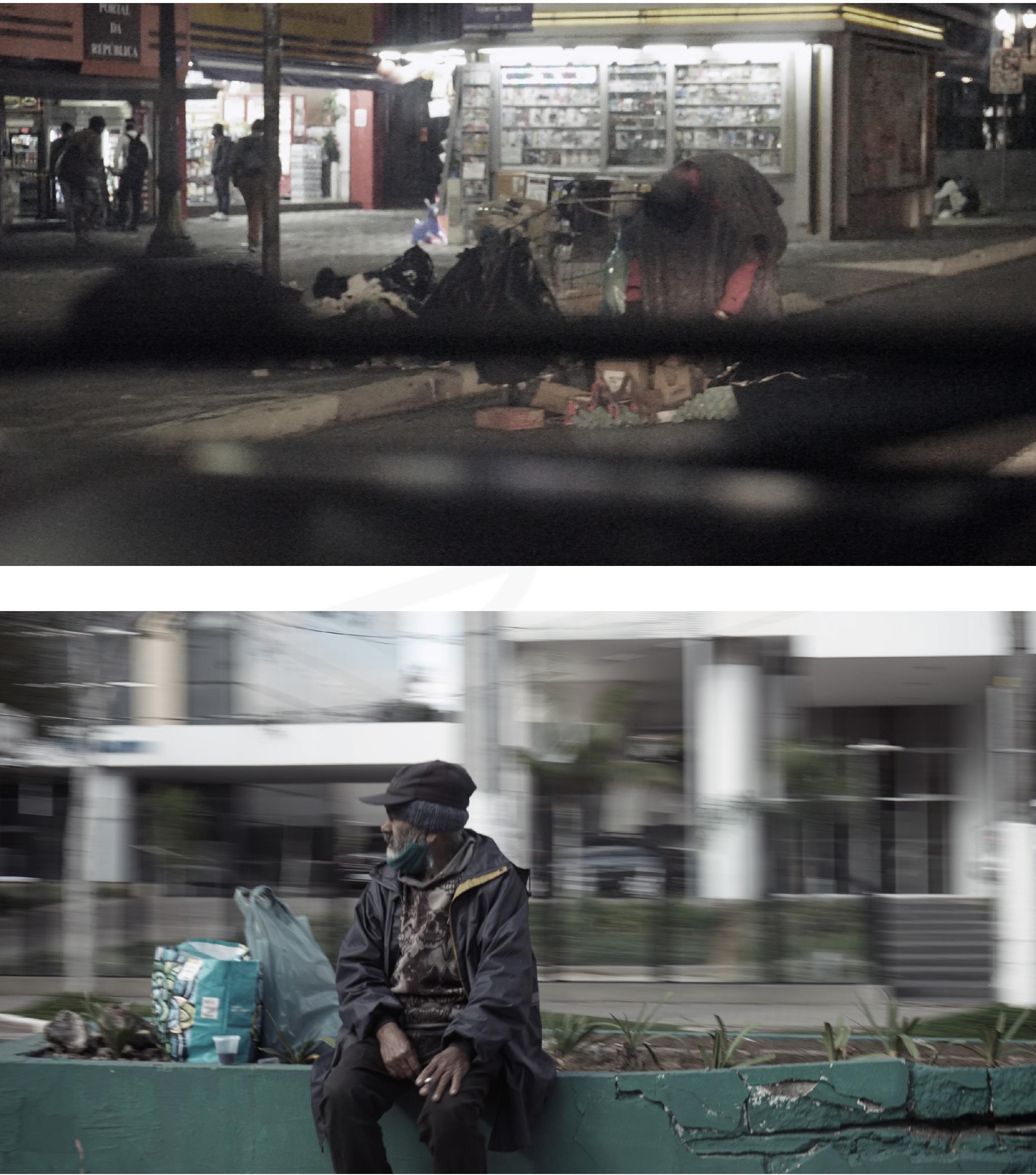

Em cima, Av. Ipiranga, 15 Julho 2020; embaixo, Av. Rebouças, 25 Julho 2020. Na página seguinte, Praça Alfredo Issa, 15 de julho 2020. Fotos da autora. 


\section{CONCLUSÃO}

Experiências equivalem a fendas, descontinuidades, riscos e oportunidades de revisão da realidade, de reposicionamento e renascimento. $\mathrm{O}$ olhar que experimenta, assim, propõe novas perspectivas diante do mundo. É indagativo e inconformado ante realidades amortecidas e apaziguadas no dia-a-dia; esvaziadas e silenciadas ainda mais em decorrência da pandemia. O olhar experimentador rasga brechas que evidenciam potencialidades e desvelam o olhar que olha sem ver ou o pensar conformado, incapaz de se indignar.

Convites ao espectador curioso, que procura e é capaz de imaginar mais, vendo além da própria imagem, as fotos aqui publicadas não pretendem encerrar ou postular nada definitivo. São fotografias móveis de percursos nas quais o choque serve como alerta, convocação a revisar costumes e crenças habituais.

Ao contrário da vivência silenciadora e paralisante descrita por Benjamin, que retira qualquer brecha de compreensão e de esperança futura, a publicação das representações multiplicadas em camadas de transparências e espanto procura estabelecer contatos com diversidades e perceber, na desigualdade, não apenas as evidentes perversidades, mas o que pode haver de comum entre todos, o que pode nos aproximar.

Mais do que o inevitável horror, consistem em perspectivas de vislumbre de novos caminhos nos quais os conflitos e discordâncias possam criar circunstâncias de se pensar e construir outra cidadania, dinâmica e ativa, não baseada na aniquilação ou no subjugo do outro. Experimentações de ímpeto inconformado, questionam individualidades e coletividades atenuadas em face ao individualismo exclusivista que trata a cidade como bem de consumo/negócio, arena de disputas na qual o lucro e a aniquilação do que se assinalou como inimigo tornam-se os objetivos maiores ou únicos.

Neste sentido, pode-se dizer que as imagens tiradas da cidade e retornadas ao público nesse artigo são representações insurgentes que reiteram a importância da cidade como lugar privilegiado de encontro entre diferenças e possibilidade de cidadania, na qual materialidades não existem apenas como receptáculos, mas 
enquanto consolidação de fluxos sociais e culturais relevantes que devem ser permanentemente revisitados e recriados pela prática coletiva cotidiana na constituição de suas memórias.

\section{REFERÊNCIAS}

AGAMBEN, Giorgio. Infância e história. Destruição da experiência e origem da história. Belo Horizonte: UFMG; 2008.

AGAMBEN, Giorgio. O que é o contemporâneo? e outros ensaios. Chapecó: Argos; 2009.

AGAMBEN, Giorgio. Profanações. São Paulo: Boitempo; 2007.

AS IMAGENS não são apenas coisas para representar. Entrevista com Georges DidiHuberman. 20 jun. 2017c. Disponível em: http://www.ihu.unisinos.br/186noticias/noticias-2017/568830-as-imagens-nao-sao-apenas-coisas-pararepresentar-entrevista-com-georges-didi-huberman. Acesso em: 16 ago. 2020.

BENJAMIN, Walter. Experiência e pobreza. In: BENJAMIN, Walter. Magia e técnica, arte e política. Ensaios sobre literatura e história da cultura. São Paulo: Brasiliense; 1987. p.114-119.

BONDÍA, Jorge Larrosa. Notas sobre a experiência e o saber de experiência. Revista Brasileira de Educação [online]. 2002, n.19, pp.20-28. Disponível em: https://scielo.br/pdf/rbedu/n19/n19a02.pdf/ Acesso em: 15 Out. 2020.

BERTOLOTTO, Rodrigo. Tudo tão desigual. Uol/Ecoa, 25 Ago. 2020. Disponível em: https://www.uol.com.br/ecoa/reportagens-especiais/pandemia-escancaradesigualdade-no-brasil-e-no-mundo-e-a-urgencia-de-reduzirgap/index.htm\#cover. Acesso em: 25 ago. 2020.

BOTTALLO, Ana. Em São Paulo, 22\% dos moradores dos bairros mais pobres já pegaram coronavírus. Folha de S. Paulo, 10. ago. 2020. Disponível em: https://www1.folha.uol.com.br/equilibrioesaude/2020/08/em-sao-paulo-22dos-moradores-dos-bairros-mais-pobres-ja-pegaramcoronavirus.shtml?utm_source=newsletter\&origin=folha. Acesso em: 17. ago. 2020.

CHARTIER, Roger. A história cultural: Entre práticas e representações. Lisboa: Difel/ Rio de Janeiro: Bertrand Brasil; 1990.

DIDI-HUBERMAN, Georges. Cascas. São Paulo: 34; 2019.

DIDI-HUBERMAN, Georges. Devolver uma imagem. In: ALLOA, Emmanuel (org.). Pensar a imagem. Belo Horizonte: Autêntica; 2017b, p: 205-225. 
DIDI-HUBERMAN, Georges. Diante da imagem. São Paulo: 34; 2013.

DIDI-HUBERMAN, Georges. Imágenes pese a todo. Memoria visual del Holocausto. Barcelona: Paidós; 2004.

DIDI-HUBERMAN, G. Remontar, remontagem (do tempo). Tradução: Milene Migliano. Caderno de Leituras, n.47. Belo Horizonte, julho, 2016. p.1-7.

DIDI-HUBERMAN, G. Sobrevivência dos vaga-lumes. Belo Horizonte: Editora UFMG; 2011.

GREGORI, Márcia Sandoval. Cartografias do levante. Revista ARA FAU USP, vol. 9, n. 9, p. 145-170, 31 maio 2020.

HARLEY, John Brian. A nova história da cartografia. O correio da UNESCO. № 8, ano 19. Brasil, ago. 1991, p.4-9.

KRENAK, Ailton. O futuro não está à venda. São Paulo: Cia. das Letras; 2020.

LARA, Wallace. Número de sem-teto nas ruas aumenta em SP durante a pandemia, dizem serviços de atendimento voluntário da cidade. G1, 29. mai. 2020.

Disponível em: https://g1.globo.com/sp/saopaulo/noticia/2020/05/29/numero-de-sem-teto-nas-ruas-aumenta-em-spdurante-a-pandemia-dizem-servicos-de-atendimento-voluntario-dacidade.ghtml. Acesso em: 18. ago. 2020.

LEVANTES: imagens e sons como forma de luta. Conferência de Georges DidiHuberman. Vídeo. 84 min. São Paulo: SESC, 2017. Disponível em: https://www.sescsp.org.br/online/artigo/11440_LEVANTES+IMAGENS+E+SON S+COMO+FORMA+DE+LUTA. Acesso em: 16 out. 2020.

NOVA, Vera Casa. Levantes. Entrevista com Georges Didi-Huberman. Revista ARS, vol. 14, n. 28. São Paulo: Jul./Dez. 2016. Disponível em: https://www.scielo.br/scielo.php?script=sci_arttext\&pid=S167853202016000200017. Acesso em: 15 out. 2020.

NUIT et brouillard. Dir.: Alain Resnais. Produção: Anatole Dauman. Roteiro: Jean Cayrol. França, 1955. Documentário. 32 min. Disponível em: https://vimeo.com/189672641. Acesso em: 18. ago. 2020.

ROLNIK, Suely. Cartografia sentimental: transformações contemporâneas do desejo. Porto Alegre: UFRGS; 2011.

ROSSI, Amanda. Do Einstein para o SUS: a rota letal da covid-19. Piauí, 10. abr. 2020. Disponível em: https://piaui.folha.uol.com.br/do-einstein-para-o-sus-rotaletal-da-covid-19/. Acesso em: 17 ago. 2020.

ROSSI, Marina. Nove milhões de brasileiros deixaram de comer por falta de dinheiro durante a pandemia. El País, 25 ago. 2020. Disponível em: https://brasil.elpais.com/brasil/2020-08-25/nove-milhoes-de-brasileiros- 
deixaram-de-comer-por-falta-de-dinheiro-durante-apandemia.html\#?sma=newsletter_brasil_diaria20200826. Acesso em: 25 ago. 2020.

SANTOS, Milton. O espaço do cidadão. São Paulo: Edusp; 2007.

SCHUMPETER, Joseph A. Capitalism, Socialism and Democracy. Londres e Nova York: Routledge; 1943. 